\title{
Contribution of cysteine residues in the extracellular domain of the F protein of human respiratory syncytial virus to its function Nicole D Day ${ }^{1}$, Patrick J Branigan1, Changbao Liu1 ${ }^{1}$, Lester L Gutshall1, Jianquan Luo ${ }^{2}$, José A Melero ${ }^{3}$, Robert T Sarisky ${ }^{1}$ and Alfred M Del Vecchio*1
}

\author{
Address: ${ }^{1}$ Department of Infectious Diseases Research, Centocor, Inc., 145 King of Prussia Road, Radnor, PA, 19087, USA, ${ }^{2}$ Department of \\ Structural Biology, Centocor, Inc., 145 King of Prussia Road, Radnor, PA, 19087, USA and ${ }^{3}$ Centro Nacional de Microbiología, Instituto de Salud \\ Carlos III, Majadahonda 28220, Madrid, Spain \\ Email: Nicole D Day - Nday2@cntus.jnj.com; Patrick J Branigan - Pbraniga@cntus.jnj.com; Changbao Liu - Cliu12@cntus.jnj.com; \\ Lester L Gutshall - Lgutshal@cntus.jnj.com; Jianquan Luo - Jluo@cntus.jnj.com; José A Melero - Jmelero@isciii.es; \\ Robert T Sarisky - Rsarisky@cntus.jnj.com; Alfred M Del Vecchio* - Adelvecc@cntus.jnj.com \\ * Corresponding author
}

Published: 24 May 2006

Virology Journal 2006, 3:34 doi:10.1186/1743-422X-3-34

This article is available from: http://www.virologyj.com/content/3/I/34

(C) 2006 Day et al; licensee BioMed Central Ltd.

This is an Open Access article distributed under the terms of the Creative Commons Attribution License (http://creativecommons.org/licenses/by/2.0), which permits unrestricted use, distribution, and reproduction in any medium, provided the original work is properly cited.
Received: 0 I November 2005

Accepted: 24 May 2006

\begin{abstract}
The mature $F$ protein of all known isolates of human respiratory syncytial virus (HRSV) contains fifteen absolutely conserved cysteine (C) residues that are highly conserved among the $\mathrm{F}$ proteins of other pneumoviruses as well as the paramyxoviruses. To explore the contribution of the cysteines in the extracellular domain to the fusion activity of HRSV F protein, each cysteine was changed to serine. Mutation of cysteines 37, 313, 322, 333, 343, 358, 367, 393, 4I6, and 439 abolished or greatly reduced cell surface expression suggesting these residues are critical for proper protein folding and transport to the cell surface. As expected, the fusion activity of these mutations was greatly reduced or abolished. Mutation of cysteine residues 212,382 , and 422 had little to no effect upon cell surface expression or fusion activity at $32^{\circ} \mathrm{C}, 37^{\circ} \mathrm{C}$, or $39.5^{\circ} \mathrm{C}$. Mutation of $\mathrm{C} 37$ and $\mathrm{C} 69$ in the F2 subunit either abolished or reduced cell surface expression by $75 \%$ respectively. None of the mutations displayed a temperature sensitive phenotype.
\end{abstract}

\section{Background}

Infection by HRSV is the single most common cause of hospitalization of infants and young children due to bronchiolitis and pneumonia and is a significant cause of morbidity and mortality the elderly and transplant recipients [1-4]. HRSV is member of the subfamily Pneumovirinae in the Paramyxoviridae family (reviewed in [5]. Three viral transmembrane proteins $(\mathrm{F}, \mathrm{G}$, and $\mathrm{SH})$ are present on the surface of the virion particle [6]. The SH and G proteins are not required for virus replication in culture, although recombinant viruses lacking these genes are attenuated in animals [7-13]. The F protein is a type 1 membrane protein required for the fusion of the viral and host cell membranes as well as the formation of mature virion particles [10,14-16]. The HRSV F mRNA is translated into a 574 amino acid precursor protein designated $\mathrm{F} 0$, which contains a signal peptide sequence at the $\mathrm{N}$-terminus that is removed by a signal peptidase in the endoplasmic reticulum (ER) [17-21]. F0 is contains 5 or $6 \mathrm{~N}$ linked glycosylation sites depending upon virus strain $[5,22,23]$. Fo is cleaved at two sites [24] by furin in the trans-Golgi $[18,19]$ removing a short, glycosylated intervening sequence and generating two subunits designated F1 ( $50 \mathrm{kDa})$ that contains a single N-linked glycosylation site and F2 ( $20 \mathrm{kDa})$ which contains two N-linked glycosylation sites [20]. The F1 and F2 chains are joined 
together by disulfide bond formation $[25,26]$ although it has not been formally demonstrated which specific residues mediate this. The mature form of the $\mathrm{F}$ protein present on the surface of the virus and infected cells is believed to consist of a homotrimer consisting of three non-covalently associated units of F1-F2. This trimer has recently been shown to be quite thermostable [27]. Similar to other type I membrane viral fusion proteins (reviewed in [28], the F1 subunit contains a hydrophobic fusion peptide region followed by two heptad repeat regions (HR1 and HR2) that are separated by an intervening cysteine-rich region. A hydrophobic transmembrane domain is located near the C-terminus of the protein followed by a short (26 residues) cytoplasmic domain containing a single cysteine residue (Figure 1). Similar to other viral fusion proteins, F-mediated fusion with the host cell membrane is believed to be mediated by insertion of the fusion peptide into the host cytoplasmic membrane followed by subsequent conformational changes resulting in the interaction of the HR1 and HR2 regions, and the formation of a 6-helix bundle structure [29-31]. This process brings the viral membrane and host cell membrane in close proximity with each other allowing for lipid mixing and the fusion of the two membranes.

Although a structure of the crystal of the HRSV F protein 6-helix bundle has been determined [31] and electron microscopy images of HRSV $F$ protein have been described [32], no detailed structural information for the entire protein exists. A partial x-ray structure of the somewhat distantly related Rubulavirus, Newcastle disease virus (NDV) $\mathrm{F}$ protein extracellular domain (ECD) $[33,34]$ has been used to build a model of the HRSV F protein ECD $[35,36]$. More recently, the complete x-ray structure of the extracellular domain of the F protein of human parainfluenza virus 3 (hPIV3) has been solved [37]. The mature $\mathrm{F}$ protein of human respiratory syncytial virus (HRSV) contains fifteen cysteine residues that are absolutely conserved in all known isolates of both A \& B subgroups of HRSV and BRSV and are highly conserved among the F proteins of the other Pneumoviruses such as pneumonia virus of mice (PVM), as well as in the Metapneumoviruses, human metapneumovirus (HMPV), and avian pneumovirus (APV) [38], and the $\mathrm{F}$ proteins of other paramyxoviruses including the well studied Newcastle disease virus (NDV) and Sendai virus $[39,40]$ F proteins (Figure 2). No studies detailing the contribution of these cysteine residues to the structure or function of the HRSV F protein have been reported. The $\mathrm{N}$-terminal signal peptide contains a single cysteine residue, however this region is removed by processing and is not present in the mature protein. A single cysteine residue is present in the cytoplasmic tail (position 550) has been shown to be the site of addition of a palmitoyl group in HRSV [41], although the cytoplasmic tail has been shown to not be required for cell fusion [42].

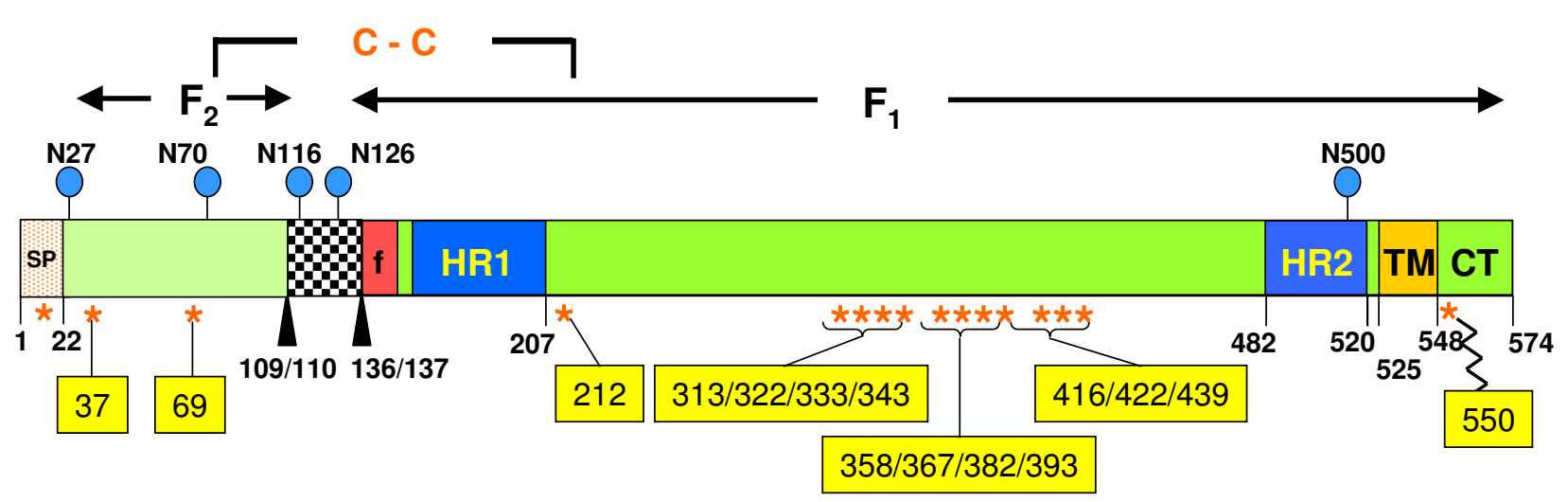

Figure I

Diagram of the HRSV F protein. A linear representation of the HRSV F precursor protein (A2 strain) is shown. Amino acid positions of individual domains are indicated with residues numbered in the context of the full-length coding region. Disulfide linked FI \& F2 subunits are delineated with arrows. The furin mediated cleavage sites are indicated by filed arrowheads. The intervening cleavage fragment is indicated as a gray box. Positions of the individual cysteine residues are depicted as asterisks. Asparagine residues (NII6 and NI26) which are sites of N-linked glycosylation are represented with circles. The site of palmitoylation at cysteine residue 550 is depicted as a jagged line. $S P=$ signal peptide; $f=$ fusion peptide; $H R I=$ heptad repeat I; HR2 = heptad repeat 2; TM = transmembrane region. Figure adapted from [5]. 


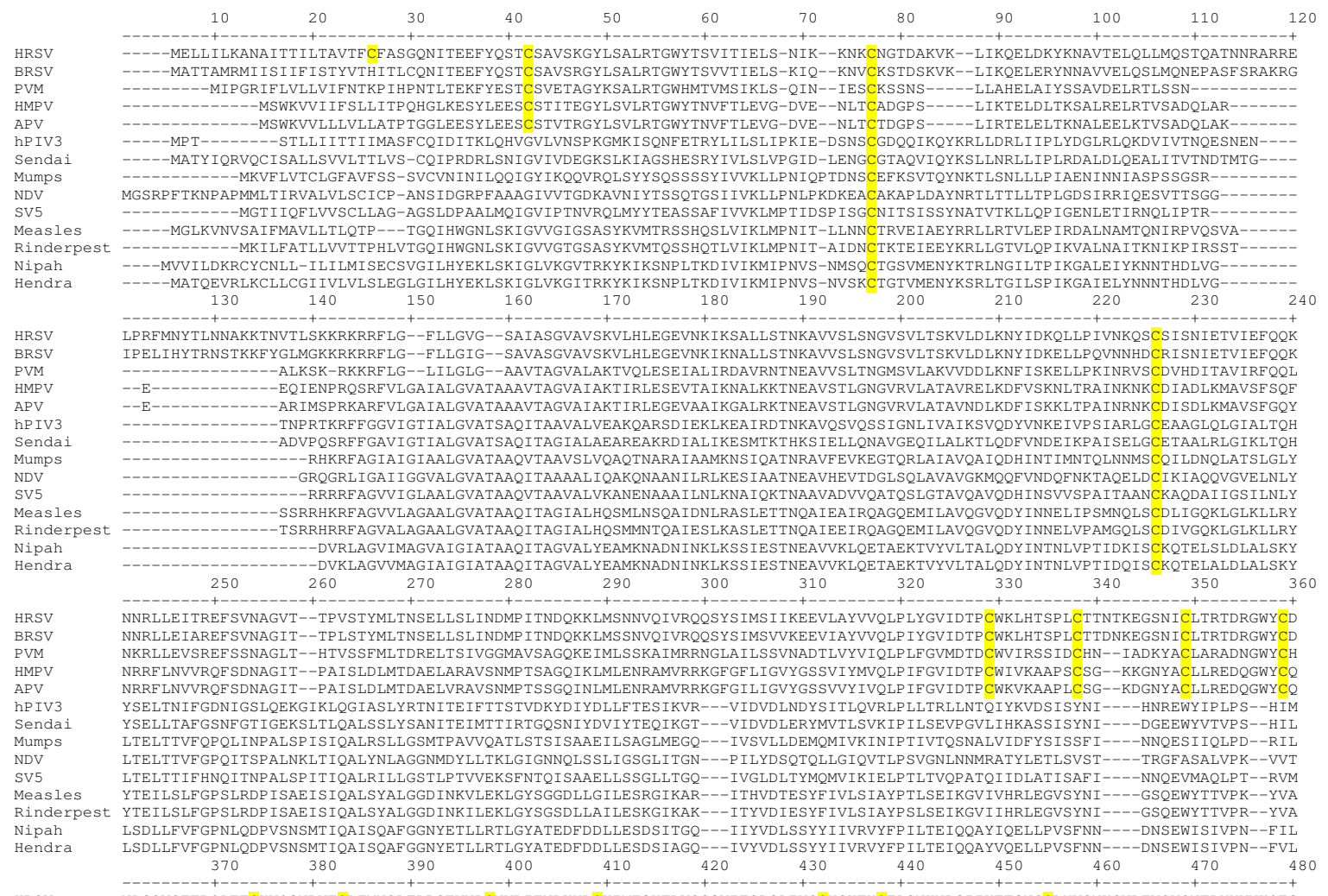
BRSV NAGSVSFFPQTETCKVQSNRVFCDTMNSLTLPTDVNLCNTD IFNTKYDCKIMTSKTD ISSSVI IS IGAIVSCYGKTKCTASNKNRGI IKTF SNGCDYVSNKGVDTVSVGNTLYYVNKLEG

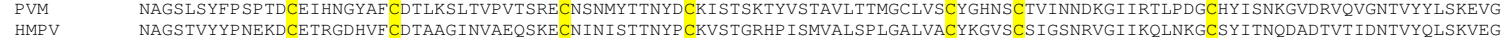
APV NAGSTVYYPNEEDCEVRSD HVF CD TAAGI INVAKESEECNRNI STTKYPCKVST GRHP I SMVALSP L GALVACYD GMSCS I GSNKVGI IRP LGKGCSY I SNQDAD TVT I DNTVYQLSKVEG hPIV3 TKGAFLGGADVKECIEAFSSY ICP SDP GFVLNHEMESC---LSGNISQCPRTTITSD IVPRYAFVNGGVVANCI TTTCTCNG I GNRINQP N NQGVKI I THKECST I G INGMLF NTN--KE Sendai SRASF LGGANIADCVESRLTYICPRDPAQLIPDSQQKC---ILGDTTRCPVTKVVDNI IPKFAFVNGGVVANCIASTCTCGTGRRP ISQDRSKGVVFLTHDNCGLIGVNGIEL YAN--RK Mumps EIGNEQWSYPAKNCKLTRHHIFCQYNEAERLSLESKLC---LAGNISACVFSP IAGSYMRRFVALDGTIVANCRSLTCLCKSPSYP IYQP DHHAVTTIDLTACQTLSLDGLDF S IV--S NDV $\quad$ QVGSVIEELDTSYCIETDLDLYCTRIVTFPMSPGIYSC---LSGNTSACMYSKTEGALTTPYMTIKGSVIANCKMTTCRCVNPPGI ISQNYGEAVSLIDKQSCNVLSLGGITLRLS--GE Measles TTGSLIQAYPASQCTITPNTVYCRYNDAQVLSDDTMAC---LQGNLTRCTFSPVVGSF LTRFVLFDGIVYANCRSMLCKCMQPAAVILQP SSSPVTVIDMYKCVSLQLDNLRFTIT--Q Measles Tinderpest

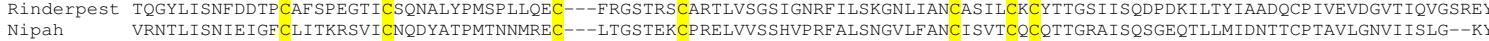

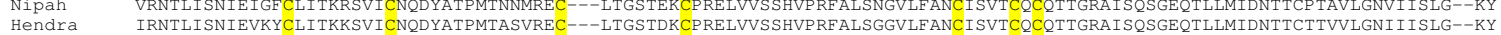

$\begin{array}{rrrrrrrrrr}490 & 500 & 510 & 520 & 530 & 540 & 550 & 560 & 570 & 580\end{array}$

HRSV KSLYVKGEP I INFYDP LVFP SDEFDASISQVNEKINQSLAF IRKSDELLHNVN--AGKSTTNIMITTIIIVIIVILLSLIAVGLLLYCKARSTP---------VTLSKDQLSG INNIA

HRSV

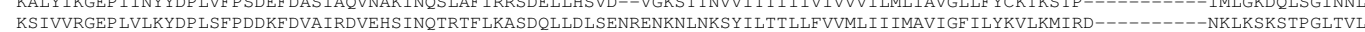
HMPV EQHVIKGRPVSSSFDPVKFPEDQFNVALDQVFES IENSQALVDQSNRI LSSAE----KGNTGE I IVI I I IAVLGSTMILVSVEIIIKKTKKP TG--------------APPELSGVTNNG

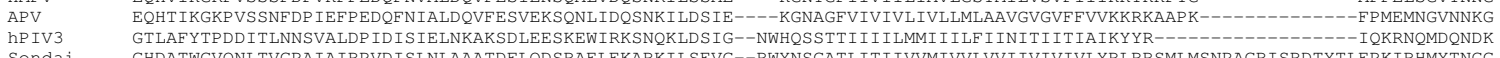
Sendai GHDATWGVQNLTVGPAIAIRPVDISLNLAAATDFLDSRAELEKARKILSEVG--RWYNSGATLITI IVVMIVVLVVI IVIVIVLYRLRRSMLMSNPAGRISRDTYTLEPKIRHMYTNGG Mumps SNITYAENLTISLSQT INTQP IDISTELSKVNASLQNAVKYIKESNHQLQSVN--VNSKIGAI IVAALVLSILSIIISLIFCCW-AYVATKEI----------RR INEKTNH INTISSSV NDV FDVTYQKNISIQDSQVI ITGNLD ISTELGNVNNSISNALNKLEESNRKLDKVN--VKLTSTSALITY IVLTIISLVFGILSL----ILACYLM----------YKQKAQQKTLLWLGNN Measles PDAVYLHR--IDLGPPISLERLDVGTNLGNAIAKLEDAKELLESSDQILRSMK--GLSSTSIVYILIAVCLGGLIGIPALICCCRGRCNKKGE---------Rinderpest PDAVYLHK--IDLGPP ISLEKLDVGTNLGNAVTKLEKAKDLIDSSDLILETIK--GASVTNTGHILVGAGLIAVVGILIVTCCCRKRSND SKV----------STVILNP GLKPDLLTGTS

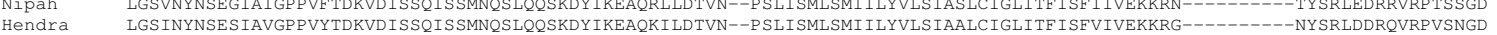

HRSV $\quad$ FSN

PVM

$\begin{array}{ll}\text { HMPV } & \text { FIPH } \\ \text { APV } & \text { FIP }\end{array}$

hPIV3 PYVLTNK

Sendai FDAMTEKR

$\begin{array}{ll}\text { Mumps } & \text { DDLIRY } \\ \text { NDV } & \text { LDQMRATTKM }\end{array}$

MV5

Rinderpest KSYVRSI

$\begin{array}{ll}\text { Nipah } & \text { LYYIGT. } \\ \text { Hendra } & \text { LYYIGT. }\end{array}$

\section{Figure 2}

Alignment of paramyxoviral F proteins. Sequence alignment was performed as described in methods. Accession numbers for the sequences of the viral $F$ proteins used for the alignment are as described in methods. Conserved cysteine residues are highlighted in yellow. 
To determine the contribution of the individual cysteine residues in the extracellular domain (ECD) to its functions, a panel of mutations in which each cysteine residue in the ECD of the HRSV F protein (residues 37, 69, 212, $313,322,333,343,358,367,382,393,416,422,439)$ was individually changed to a serine, and the effect of these mutations upon the function of the HRSV F protein was determined.

\section{Results}

To better understand our results, the molecular structure of hRSV F protein was modeled using hPIV3 structure [pdb code $1 \mathrm{ztm}$ ] [37] as a template. The sequence alignment was essentially the same as previously described [36] with a small adjustment of residues between 331 and 346 to allow all pairs of cysteine residues in the extracel- lular domain to be positioned close enough to form disulfide bonds. The trimer model of RSV F protein was constructed using Modeler software (Accelrys, CA) without further refinement. The resulting predicted disulfide bond pattern is 37-439, 69-212, 322-333, 313-343, $358-367,382-393$, and 416-422 (Figure 3).

To assess the effect of the cysteine mutations on protein expression, 293T cells were transfected with plasmids encoding either the wild-type F protein or those containing the individual cysteine mutations followed by metabolic labeling with $\left.{ }^{35} \mathrm{~S}\right]$-methionine-cysteine mixture. Cell lysates were prepared and immunoprecipitated with a cocktail of four anti-HRSV F mAbs (palivizumab, 47F, Mab19, and 101F) directed against the two major antigenic sites II and IV, V, VI [43] as previously described
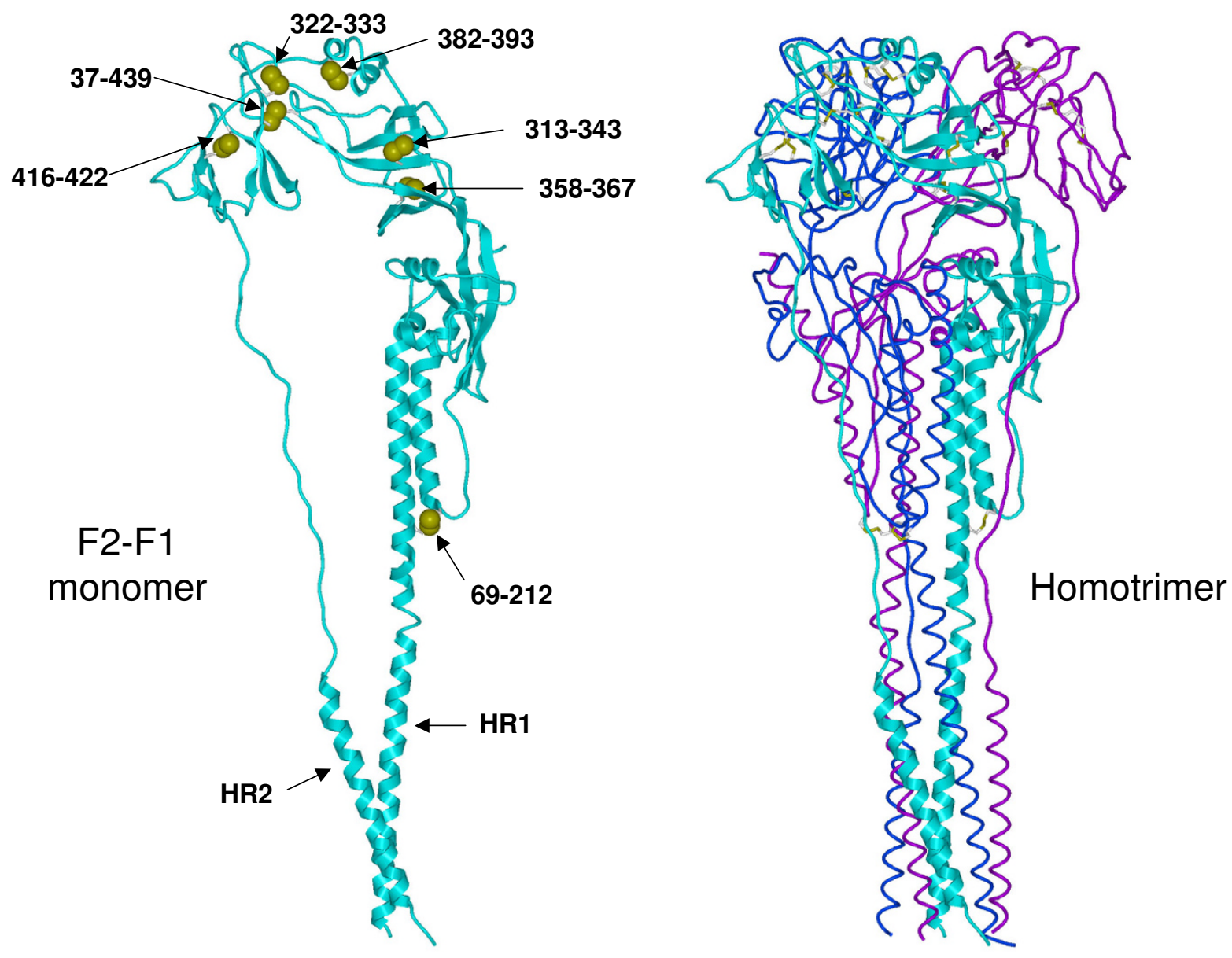

\section{Figure 3}

Computer model of the HRSV F protein. The molecular structure of HRSV F protein ECD was modeled using the human parainfluenza virus 3 virus $\mathrm{F}$ protein ECD structure as template as described in methods. Ribbon diagrams of the FI-F2 monomer (left) and F protein homotrimer (right) are shown. Heptad repeat I (HRI) and heptad repeat 2 (HR2) are indicated with arrows. Cysteine residues are depicted as yellow balls with specific residue disulfide pairs indicated on the monomer. 
[44]. Levels of total immunoprecipitated F protein as well as the degree of cleavage of the F0 precursor into the F1 and F2 subunits were determined (Figure 4). A non-HRSV F related cellular band (present in lysates from cells transfected with empty vector (-) or beta-galactoside expression vector negative controls) that migrated slightly slower than the F0 precursor was also immunoprecipitated under these conditions. As shown in figure 4, mutation of extracellular cysteine residues 212, 382, 422 had little to no discernable effects on the levels of total immunoprecipitated protein or the degree of F0 cleavage relative to those observed for the wild-type HRSV F protein. Furthermore, the bands corresponding to the F1 and F2 subunits derived from these mutations migrated similarly to those from the wild-type HRSV F protein suggesting that these mutations had no gross effect on glycosylation. These findings are intriguing given that these three cysteine residues are absolutely conserved not only in the F proteins of other Pneumovirinae, but also in the F proteins of the Paramyxovirinae as well (Figure 2). In contrast, mutation of cysteine residues $37,313,333,343,358,367,393,416$, or 439 to serine all dramatically reduced or abolished the levels of total F protein immunoprecipitated as well as the degree of F0 precursor cleavage as determined by the levels of F1 and F2. These results suggest that either mutation of these cysteine residues to serine grossly affected the translation or folding of the $\mathrm{F}$ protein such that it was unstable or rapidly degraded, or that these mutations reduced the efficiency of binding of the four antibodies used in the immunoprecipitation. Based upon the model,
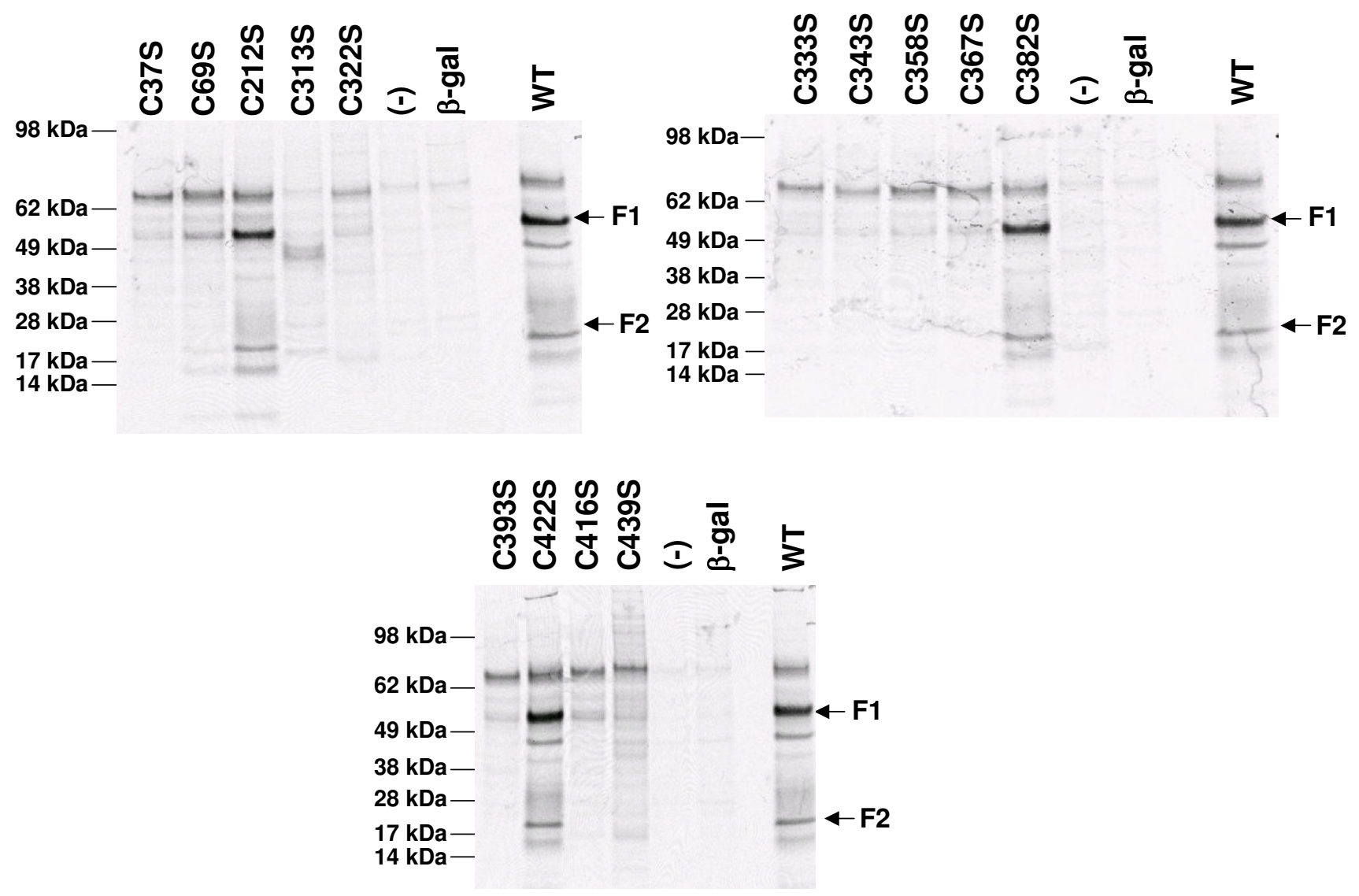

\section{Figure 4}

Immunoprecipitation of HRSV F cysteine mutations. 293T cells were mock transfected (-), transfected with a plasmid expressing beta-galactosidase (b-gal), or plasmids encoding the wild-type (WT) HRSV F protein or various cysteine mutants (listed above lanes), followed by metabolic labeling with [ $\left.{ }^{35} \mathrm{~S}\right]$-methionine/cysteine mixture, and immunoprecipitation as described in [44]. The positions of molecular weight size markers are indicated. The positions of the FI and F2 subunits are indicated with arrows. 
residues 382 and 422 form disulfide bonds with residues 393 and 416 respectively. It is intriguing that mutation of one residue in the pair has no effect, while mutation of its bond partner residue has a dramatic effect. Together, these data would suggest that the formation of a disulfide bond between residues 382 and 393 or 416 and 422 is not required, but rather suggests the presence of a cysteine residue at positions 393 and 416 is critical. It is possible that loss of a disulfide partner in one case leads to aberrant disulfide bond formation by that free cysteine, while in the other case, the cysteine remains free and unbonded. Further work is needed to clarify the exact effect of such mutations. As these antibodies have been shown to recognize largely non-conformational epitopes $[43,45]$, it would be unlikely to have a simultaneous loss of binding to both antigenic sites, thus we favor the interpretation that these cysteine mutations disrupted proper global protein folding and stability. Very low levels of F1 and F2 were observed with mutations C69S and C322S. Mutation C313S resulted in the appearance of a novel immunoprecipitating band migrating at approximately $45 \mathrm{kDa}$ suggesting altered proteolytic cleavage or truncated translation. Further analysis is required to determine the exact nature of this band. Mutation of cysteine 69 to serine (C69S) reduced, but did not abolish expression or protein cleavage. These results suggest that mutation of cysteine residues 212,382 , and 422 did not disrupt folding sufficiently to affect processing of F0 to F1 and F2. Mutation of residues 69 and 322 dramatically reduced the levels of total protein immunoprecipitated as well the levels of F0 processed to F1 and F2. None of the mutations appeared to grossly affect glycosylation as the F0 and F1 and F2 subunits of all the cysteine mutations migrated similarly, although our gel system would not allow resolution of minor changes in glycosylation.

To determine the role of the individual cysteine residues in cell surface expression, 293T cells transfected with plasmids expressing either wild-type HRSV F or the panel of cysteine mutations were analyzed by ELISA using palivizumab under either permeabilizing (to measure total protein) or non-permeabilizing (to measure cell-surface only) conditions. Values were calculated as percents relative to wild-type HRSV F after adjusting for background signal from the vector only control. As shown in Figure 5, cysteine mutations $\mathrm{C} 212 \mathrm{~S}$, C382S, and C422S had similar levels of cell surface expression levels as wild-type HRSV F protein. Mutation of cysteine 69 to serine (C69S) reduced both total and cell surface expression by $25 \%$ and $72 \%$ respectively, but did not abolish expression or protein processing. Similar to the metabolic labeling results showing reduced total protein levels, mutations C37S, C313S, C322S, C333S, C343S, C358S, C367S, C393S, C416S, and $\mathrm{C} 439 \mathrm{~S}$ all had reduced levels of total protein (permeabilizing conditions) ranging from $49-92 \%$ reduction rel-

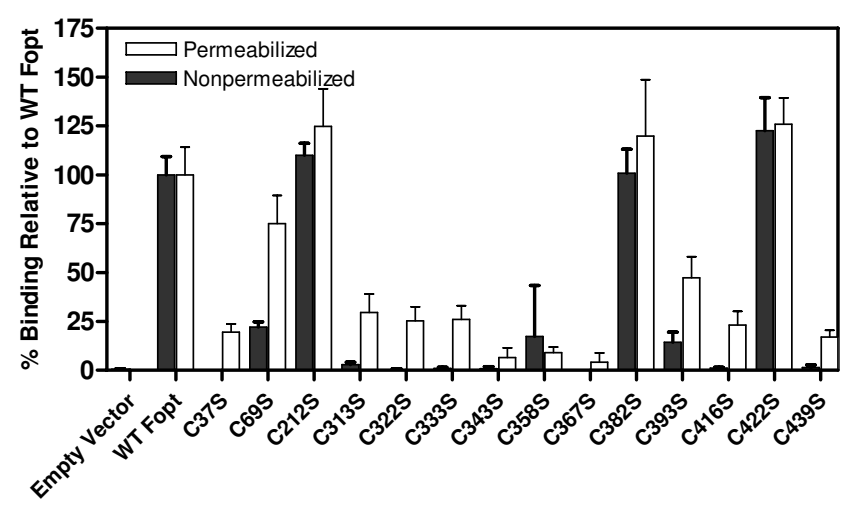

Figure 5

Expression of cysteine mutations measured by

ELISA. 293T cells were transfected with plasmids encoding the wild-type HRSV F (WT), empty vector cassette (EV) or the various cysteine mutants (listed below lanes), followed by fixation and analysis using an ELISA as described in methods. Results are presented relative to values obtained with wildtype HRSV F which was set at 100\%, and represent the average of three separate determinations. Results obtained using permeabilizing conditions are depicted with open bars.

Results obtained using non-permeabilizing conditions are depicted with a solid bars.

ative to wild-type F protein (Table 1). However, when the level of cell surface expression was examined by ELISA under non-permeabilizing conditions, all mutations had either low ( $8 \%$ for C393S, 3\% for C313S) or no detectable levels of cell surface protein. This finding suggests that residues $37,313,322,333,343,358,367,393,416$, and 439 are critical for cell surface expression most likely through their role in proper protein folding and disulfide bond formation. These results also suggest that the reduction in cell surface binding by the antibodies used in this study is not due to a diminished ability of these antibodies to recognize the cysteine mutations, as in several cases, F protein was clearly detected under permeabilizing conditions (Figure 5, C37S, C313S, C322S, C333S, C343S, C358S, C393S, C416S, C439S), but little to no F protein was detected under non-permeabilizing conditions. However, these results obtained using this assay can not rule out the possibility that in instances where cell surface $F$ protein was not detected (under non-permeabilizing conditions), the protein encoded by these mutations was misfolded in such a way as to block the epitope recognized by the antibody.

To extend these results, the effect of the cysteine mutations upon the level of cell surface expression was examined by flow cytometry using four different antibodies, 47F [46], 101F (a monoclonal which recognizes the site IV, V, VI region), palivizumab [47] or mAb19 [48] directed against one of two major antigenic sites (II or IV, 
Table I: Summary of results for HRSV F cysteine mutants. Processing is defined as relative amounts of F0, FI, and F2, and is described as being equivalent to wild-type HRSV F protein (complete) or reduced. Cell surface and total expression were measured by ELISA under permeabilizing (total $F$ protein) or non-permeabilizing (cell surface $F$ protein) conditions using palivizumab as described in methods and reported as percent relative to wild-type HRSV F protein. Reactivity with neutralizing mAbs (palivizumab, Mab I9, 47F, and IOIF) as determined by flow cytometry is shown and reported as percent relative to wild-type HRSV F protein. Cell fusion activity is reported as luciferase activity measured at $32^{\circ} \mathrm{C}, 37^{\circ} \mathrm{C}$, and $39.5^{\circ} \mathrm{C}$ as described in [44]. All values are expressed as $\%$ relative to wildtype at the respective temperatures.

\begin{tabular}{|c|c|c|c|c|c|c|c|c|c|c|}
\hline & \multirow{2}{*}{$\begin{array}{l}\text { Protein } \\
\text { Processin } \\
\quad \text { g }\end{array}$} & \multicolumn{2}{|c|}{ ELISA } & \multicolumn{4}{|c|}{$\begin{array}{c}\text { Cell surface expression (Flow } \\
\text { cytometry) }\end{array}$} & \multicolumn{3}{|c|}{ Cell fusion (\% of WT) } \\
\hline & & $\begin{array}{c}\text { Cell surface } \\
\text { protein (Non- } \\
\text { permeabilized) }\end{array}$ & $\begin{array}{c}\text { Total protein } \\
\text { (permeabilized } \\
\text { ) }\end{array}$ & $\begin{array}{c}\text { Palivizu } \\
\text { mab }\end{array}$ & $47 F$ & IOIF & mAbI9 & $32^{\circ} \mathrm{C}$ & $37^{\circ} \mathrm{C}$ & $39.5^{\circ} \mathrm{C}$ \\
\hline Wild-type & complete & 100 & 100 & 100 & 100 & 100 & 100 & $100 \%$ & $100 \%$ & $100 \%$ \\
\hline C37S & minimal & 0.00 & 51 & 7 & 3 & 2 & 4 & $8 \%$ & $8 \%$ & $12 \%$ \\
\hline C69S & reduced & 25 & 72 & 22 & 19 & 21 & 20 & $10 \%$ & $12 \%$ & $12 \%$ \\
\hline $\mathrm{C} 212 \mathrm{~S}$ & complete & 117 & 103 & 37 & 43 & 46 & 39 & $52 \%$ & $44 \%$ & $34 \%$ \\
\hline $\mathrm{C} 313 \mathrm{~S}$ & reduced & 3 & 44 & 23 & 11 & 4 & 1 & $6 \%$ & $5 \%$ & $5 \%$ \\
\hline C322S & minimal & 0 & 35 & 5 & 1 & 3.5 & 0 & $7 \%$ & $5 \%$ & $6.5 \%$ \\
\hline C333S & minimal & 0 & 41 & 8 & 3 & 3 & 0.5 & $12 \%$ & $8.5 \%$ & $10 \%$ \\
\hline C343S & minimal & 0 & 22 & 4 & 0 & 1.5 & 0 & $14 \%$ & $17 \%$ & $19 \%$ \\
\hline C358S & minimal & 0 & 17 & 3 & 0 & 2 & 0 & $7 \%$ & $4 \%$ & $6 \%$ \\
\hline C367S & minimal & 0 & 8 & 8 & 3 & 9 & 1.5 & $10 \%$ & $8 \%$ & $9 \%$ \\
\hline C382S & complete & 103 & 90 & 86 & 102 & 96 & 88 & $105 \%$ & $91 \%$ & $100 \%$ \\
\hline C393S & reduced & 8 & 42 & 13 & 10 & 13 & 7 & $14 \%$ & $10 \%$ & $12 \%$ \\
\hline C4I6S & minimal & 0 & 43 & 4 & 3 & 5 & 0 & $5.5 \%$ & $4 \%$ & $4 \%$ \\
\hline C422S & complete & $14 \mid$ & 132 & 90 & 93 & 81 & 81 & $140 \%$ & $122 \%$ & $146 \%$ \\
\hline C439S & minimal & 0.4 & 26 & 7 & 4 & 4 & 1 & $50 \%$ & $29 \%$ & $30 \%$ \\
\hline
\end{tabular}

$\mathrm{V}, \mathrm{VI}$ ) in the F protein. Consistent with results obtained using ELISA under non-permeabilizing conditions, flow cytometry analysis demonstrated that mutation of cysteine residues 37, 313, 322, 333, 343, 358, 367, 393, 416 , and 439 reduced binding of all four antibodies, while mutation of cysteine mutants C382S, and C422S retained similar levels of antibody binding as the wildtype $\mathrm{F}$ protein (Table 1 ). As the same set of cysteine mutations that reduced or abolished F0 protein cleavage and cell surface expression, also reduced or abolished cell surface binding of the four mAbs tested here, we conclude that cysteine residues 37, 313, 322, 333, 343, 358, 367, 393,416 , and 439 play a key role in the proper folding, processing, and cell surface transport of the HRSV F protein. Again, as the epitopes of these antibodies are directed against two different antigenic regions of $\mathrm{F}$ protein and have been shown to be largely non-conformational $[43,45]$, we suggest that it is unlikely that the inability to detect these cysteine mutation $\mathrm{F}$ proteins on the cell surface is attributable to protein misfolding which would simultaneously block the epitopes recognized by these four different antibodies, but rather reflects a true defect in cell surface transport caused by these mutations. Interestingly, mutation of residue $\mathrm{C} 212$, which had wild-type levels of protein expression as determined by ELISA, appeared to have somewhat reduced levels of cell surface protein (37-47\% of wild-type) as determined by flow cytometry. Although the exact reason for this is not clear, it could reflect a sensitivity of this particular mutant (folding, reactivity to fixation agent, etc.) to the differences in the experimental conditions used for ELISA and flow cytometry.

To assess the functionality of these cysteine mutations, a cell fusion assay was used as previously described [44]. As mutation of cysteine residues in other viral fusion proteins has been reported to cause a temperature-sensitive ( $t s)$ phenotype [49], we also examined the fusion activity of the panel of cysteine mutations at $32^{\circ} \mathrm{C}$ and $39.5^{\circ} \mathrm{C}$ as HRSV mutants sensitive for these two temperatures have been previously described $[50,51]$. The overall levels of wild-type HRSV F-mediated cell fusion are reduced by approximately $50 \%$ at either $32^{\circ} \mathrm{C}$ or $39.5^{\circ} \mathrm{C}$ relative to $37^{\circ} \mathrm{C}[42]$. As shown in figure 6 , mutation of cysteine residues $37,69,313,322,333,343,358,367,393,416$, and 439 reduced cell fusion activity to similar levels as a previously described point mutation in the fusion peptide region (pL138R) [44]. In contrast, mutations C382S and C422S had cell fusion activity equivalent to wild-type HRSV F protein. Mutation of cysteine residue 212 reduced fusion activity by $40-50 \%$. This finding correlates with the reduced cell surface expression observed using flow 


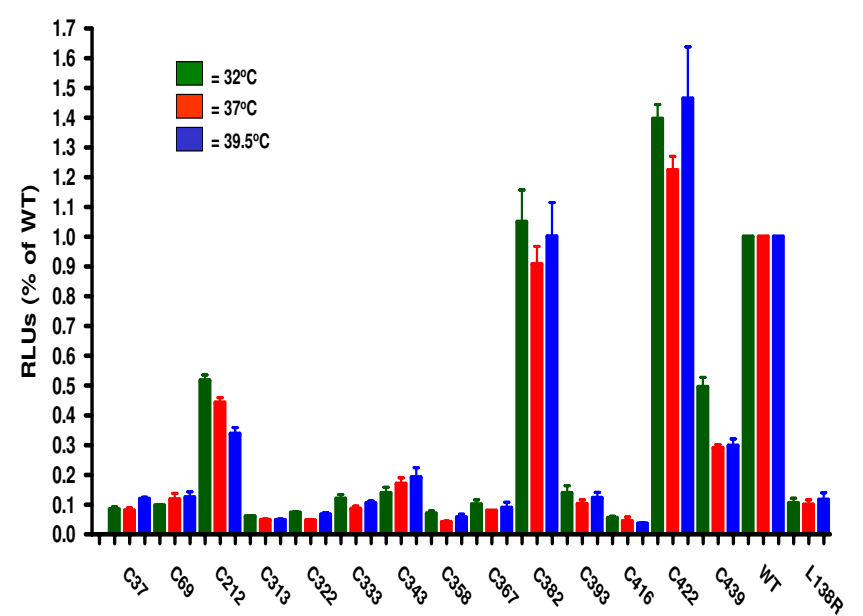

Figure 6

Fusion activity of cysteine mutations. 293T cells were transfected with plasmids encoding either the wild-type HRSV $F$ protein or the panel of cysteine mutants and fusion activity was measured at $32^{\circ} \mathrm{C}, 37^{\circ} \mathrm{C}$, or $39.5^{\circ} \mathrm{C}$ as described in [44]. Fusion activity is represented as relative light units (RLUs), and values represent the average of three separate determinations.

cytometry. Although the absolute levels of HRSV F-mediated cell fusion were reduced at both $32^{\circ} \mathrm{C}$ and $39.5^{\circ} \mathrm{C}$ relative to $37^{\circ} \mathrm{C}$ for all proteins including wild-type (Figure 6), there were no differences observed in their relative fusion activities of the cysteine mutations at either $32^{\circ} \mathrm{C}$ and $39.5^{\circ} \mathrm{C}$ suggesting a lack of a gross $t$ s phenotype for fusion for any of these mutations (Figure 4B).

\section{Discussion}

Limited direct structure-function data exists for the HRSV F protein. This study utilizes a genetic approach to analyze the contribution of the individual cysteine residues in the extracellular domain in protein expression and cell fusion of the HRSV F protein and represents the first analysis of the contribution of the cysteine residues of the HRSV F protein ECD to its function. Generally, cysteine residues are critical for folding and provide structural stability to a protein via the formation of disulfide bonds. Mutation of cysteine residues 37, 313, 322, 333, 343, 358, 367, 393, 416 , and 439 abolished or reduced cell surface expression to less than $7 \%$ of wild type HRSV F protein. This suggests that these residues play a key role in the proper folding and subsequent transport through the Golgi to the cell surface. Identification of the stages at which these specific cysteine mutations block the folding, maturation, and transport of the HRSV F protein is currently ongoing. Mutation of cysteine residues can often lead to a temperature sensitive ( $t s)$ phenotype such as that observed for the herpes simplex type $1 \mathrm{gD}$ glycoprotein [49]. The lack of an observable ts phenotype in this study is supported by the high thermostability of the HRSV F protein among paramyxoviruses [27].

From direct mapping of disulfide bonds in Sendai virus [39], and based upon the positional conservation of the cysteine 69 residue in the HRSV F proteins with that of Sendai virus $\mathrm{F}$ protein and the F proteins from other of the Paramyxoviridae, it is likely that cysteine residues 69 and 212 participate in the disulfide linkage between the F1 and F2 subunits. The Pneumovirinae members have a positionally conserved second cysteine residue in the F2 subunit (corresponds to residue 37 in HRSV F protein) (Figure 2) not found in the other Paramyxovirinae. In the model of the HRSV F ECD, this cysteine residue is predicted to make a disulfide bond with cysteine residue 439, which is also only conserved in the $\mathrm{F}$ proteins of the Pneumovirinae members and not found in the F proteins of the other Paramyxovirinae members. This would suggest that two disulfide bonds are formed between the F1 and F2 subunits. We are currently performing direct biochemical mapping of the disulfide linkages to formally demonstrate this. This could explain, in part, the unique thermostability described for the HRSV F protein ECD [27].

HRSV is a significant human pathogen, and the F protein has been identified as the target of multiple neutralizing antibodies $[47,52,53]$ as well as small molecule inhibitors [54-58]. As such, the HRSV F protein represents a critical viral target for the development of new and improved preventions and treatments for HRSV induced disease. A greater understanding of its structure-function relationships would greatly facilitate the development of these new agents. The results of this study provide further support that the highly conserved HRSV F protein cysteine residues play a critical role in the structure and function of this protein. As disulfide bonds have been shown to play roles beyond proper protein folding and stabilization of protein structure [59], it is tempting to speculate that, similar to HIV [60], the disulfide bonds of the Pneumovirus F proteins may have a direct role in fusion. Our modeling and analysis suggest the presence of two disulfide bonds which join the F1 and F2 subunits of the HRSV F protein. If formally demonstrated, this would highlight a distinct structural feature of the F proteins of the Pneumovirinae not described for the F proteins of the Paramyxovirinae.

\section{Methods}

\section{Cells, plasmids and transfections}

$293 \mathrm{~T}$ cells were grown at $37^{\circ} \mathrm{C}$ in a humidified atmosphere of $5 \% \mathrm{CO}_{2}$ and maintained in Dulbecco's modified Eagle media (DMEM) with $4 \mathrm{mM}$ L-glutamine adjusted to contain $1.5 \mathrm{~g} / \mathrm{L}$ sodium bicarbonate, $4.5 \mathrm{~g} / \mathrm{L}$ glucose and $10 \%$ FBS. Cells were tested and confirmed to be free of mycoplasma contamination. Plasmid pHRSVFoptA2, 
which expresses the HRSV F protein of the A2 strain whose sequence was codon optimized and derived from a known infectious HRSV cDNA [61], has been previously described [44] and served as the template for the generation of the panel of cysteine mutations by site directed mutagenesis using the QuikChange ${ }^{\circledast}$ Site-Directed Mutagenesis kit (Stratagene $e^{\circledast}$, La Jolla, CA). Cells were transiently transfected using FuGENE 6 reagent (Roche Applied Science, IN) as previously described [44].

\section{Metabolic labeling and immunoprecipitation}

[35S]-methionine/cysteine radiolabeled cell lysates were prepared and immunoprecipitated with a cocktail of four anti-HRSV F mAbs (palivizumab, 47F, Mab19, and 101F) directed against the two major antigenic sites II and IV, V, VI [43] as previously described [44].

\section{ELISA}

The binding of neutralizing monoclonal antibodies (mAbs) to HRSV F protein was assayed by ELISA using 293 T cells transiently transfected with plasmids expressing either wild-type $\mathrm{F}$ protein, the panel of cysteine mutants, or a vector only control. 293T cells $\left(2.0 \times 10^{4}\right.$ cells/well) were plated the day before transfection in 96well plates in DMEM, supplemented with 1.5 gms./liter sodium bicarbonate and 10\% FBS. A total of 50 ngs of plasmid DNA was complexed with $0.15 \mu$ of FuGENE 6 reagent and incubated 20 minutes room temperature in OptiMEM reduced-serum medium prior to addition to cells in serum containing medium. At 20-24 hours posttransfection, cells were assayed for binding of palivizumab under permeabilizing or non-permeabilizing conditions. Cells were fixed by the addition of $0.05 \%$ glutaraldehyde (Sigma) in 1X PBS for 15 minutes at room temperature. Cells were then either washed under conditions which permeabilizing ( $0.1 \%$ Triton-X100 in PBS) or non- permeabilizing $(0.05 \%$ Tween-20 in PBS) conditions. These conditions were verified using an anti-RSV N protein mAb (clone \# M291207, Fitzgerald Industries International, Concord, MA) and HRSV infected cells. HRSV N protein is only produced within the cytoplasm of HRSV infected cells. The anti-N mAb yields a strong positive signal on infected cells when the wash buffer containing $0.1 \%$ Triton-X100 is used, but not when wash buffer containing $0.05 \%$ Tween 20 is used (data not shown). Cells were blocked for one hour with SuperblockTM (Pierce Biotechnology, Inc., Rockford, IL) followed by incubation with either $1 \mu \mathrm{g} / \mathrm{ml}$ chimeric $101 \mathrm{~F} \mathrm{IgG}, 1 \mu \mathrm{g} /$ $\mathrm{ml}$ palivizumab or a 1:600 dilution of mAb19 hybridoma supernatant for one hour at room temperature. Samples were then incubated with an anti-human IgG-HRP or an anti-mouse IgG-HRP as appropriate (Amersham Biosciences, Inc.) at 1:800 for one hour at room temperature followed by detection with TMB substrate (Sigma, Inc.). The reaction was stopped with the addition of $2 \mathrm{~N}$ sulfuric acid, and the optical density at $450 \mathrm{~nm}$ was read. Values were calculated as percents relative to wild-type HRSV F after adjusting for background signal from the vector only control.

\section{Flow cytometry}

To confirm cell surface expression, 293T cells were transfected with plasmids expressing either wild-type F protein, the panel of cysteine mutants or a vector only control in either 6-well or 96-well formats as described above. Cells were fixed with $2 \%$ paraformaldehyde in PBS for 15 minutes at $4{ }^{\circ} \mathrm{C}$. Cells were washed with PBS containing $2 \%$ FBS and then stained with either a chimerized human version of $101 \mathrm{~F}$ (murine $\mathrm{V}$ region grafted onto human IgG1 $\mathrm{\kappa}$ framework) or palivizumab (IgG1 $\kappa)$ at $1 \mu \mathrm{g} / \mathrm{ml}$ with an anti-human IgG-Alexa-Fluor-488 conjugated secondary (Molecular Probes, Eugene, OR) for analysis with the FACSCalibur (BD Bisociences) and determining the mean fluorescence intensity. Data analysis was performed with Cell Quest and FloJo Analysis Software. Values were calculated as percents relative to wild-type HRSV F after adjusting for background signal from the vector only control.

\section{Cell fusion assays}

Cell fusion assays were conducted as previously described [44]. Briefly, one population of 293T cells was co-transfected with pHRSVFOptA2 and pBD-NFкB (effectors cells), and another population of $293 \mathrm{~T}$ cells was transfected with the pFR-Luc luciferase reporter plasmid (reporter cells). At 24 hours post transfection, effector cells were mixed with an equal amount of reporter cells in a 96-well plate and incubated an additional 24 hours prior to measurement of luciferase activity using the Steady Glo Luciferase reporter system (Promega, Inc.).

\section{Computer modeling}

The molecular structure of HRSV F protein ECD was modeled using the human parainfluenza virus 3 virus $F$ protein ECD structure as template [pdb code 1ztm], essentially in the same way as previously described [36] with a small adjustment of the residues between 331 and 346, thus allowing all pairs of cysteine residues to be positioned close enough to form disulfide bonds. Sequence alignment was carried out in ICM (Molsoft, CA) and manually adjusted. The monomer molecular model was first generated in ICM and then the trimer was assembled.

\section{Sequence alignment}

Sequence alignment was performed using the CLUSTAL $\mathrm{W}$ method in MegAlign program (version 5.05) from DNASTAR, Inc. (Madison, WI). Genbank accession numbers for the sequences of the viral F proteins used for the alignment are: HRSV [61], BRSV (NC 001989), PVM (AY729016), HMPV (NC_004148), APV (AY590688), hPIV3 (NC 001796), Sendai virus (NC 001552), Mumps 
virus ( $\underline{\mathrm{NC} 002200})$, NDV ( $\underline{\mathrm{AF} 309418})$, Simian parainfluenza virus 5 (SV5) (NC 006430), Measles virus (P69353), Rinderpest virus (C 006296), Nipah virus (NC_002728), Hendra virus (NC_001906).

\section{Competing interests}

The authors $\mathrm{PB}, \mathrm{CL}, \mathrm{ND}, \mathrm{LG}, \mathrm{JL}, \mathrm{RS}$, and $\mathrm{AD}$ declare that are employees of Centocor, Inc. which provided supported for this work. JM is Director of the Centro Nacional de Microbiología Fundamental, Instituto de Salud Carlos III, and is a consultant for Centocor, Inc.

\section{Authors' contributions}

$\mathrm{PB}, \mathrm{CL}$, and ND contributed equally to this work. PB and ND performed the ELISA assays, immunoprecipitations, and flow cytometry. CL generated reagents and performed the fusion assays. LG conducted site-directed mutagenesis of the HRSV F protein. JL generated the computer model of the HRSV F ECD. AD and RS participated in the design of the experiments, oversight of the conduct of the experiments, and $\mathrm{AD}, \mathrm{RS}$, and JM participated in the interpretation of the results.

\section{Acknowledgements}

We thank Geraldine Taylor for generously providing mAbl 9 hybridoma supernatant as well as helpful discussions and comments. We thank William Glass, Jarrat Jordan, and Lamine Mbow for critical review of this manuscript.

\section{References}

I. Han LL, Alexander JP, Anderson LJ: Respiratory syncytial virus pneumonia among the elderly: an assessment of disease burden. J Infect Dis 1999, 179:25-30.

2. Ison MG, Hayden FG: Viral infections in immunocompromised patients: what's new with respiratory viruses? Curr Opin Infect Dis 2002, 15:355-367.

3. Thompson WW, Shay DK, Weintraub E, Brammer L, Cox N, Anderson LJ, Fukuda K: Mortality associated with influenza and respiratory syncytial virus in the United States. JAMA 2003, 289: 179-186.

4. Whimbey E, Ghosh S: Respiratory syncytial virus infections in immunocompromised adults. Curr Clin Top Infect Dis 2000, 20:232-255.

5. Collins PL, Chanock RM, Murphy BR: Respiratory syncytial virus. In Fields Virology Volume I. Fourth edition. Edited by: Knipe DM and Howley PM. Philadelphia, Lippincott, Williams, and Wilkins; 200I:| |443-I 485

6. Huang YT, Collins PL, Wertz GW: Characterization of the 10 proteins of human respiratory syncytial virus: identification of a fourth envelope-associated protein. Virus Res 1985, 2:157-173.

7. Bukreyev A, Whitehead SS, Murphy BR, Collins PL: Recombinant respiratory syncytial virus from which the entire $\mathrm{SH}$ gene has been deleted grows efficiently in cell culture and exhibits site-specific attenuation in the respiratory tract of the mouse. J Virol 1997, 71:8973-8982.

8. Jin $H$, Zhou H, Cheng $X$, Tang R, Munoz M, Nguyen N: Recombinant respiratory syncytial viruses with deletions in the NSI, NS2, SH, and M2-2 genes are attenuated in vitro and in vivo. Virology 2000, 273:210-218.

9. Karron RA, Buonagurio DA, Georgiu AF, Whitehead SS, Adamus JE, Clements-Mann ML, Harris DO, Randolph VB, Udem SA, Murphy BR, Sidhu MS: Respiratory syncytial virus (RSV) SH and G proteins are not essential for viral replication in vitro: clinical evaluation and molecular characterization of a cold-passaged, attenuated RSV subgroup B mutant. Proc Natl Acad Sci U S A 1997, 94:1396|-13966.

10. Techaarpornkul S, Collins PL, Peeples ME: Respiratory syncytial virus with the fusion protein as its only viral glycoprotein is less dependent on cellular glycosaminoglycans for attachment than complete virus. Virology 2002, 294:296-304.

II. Techaarpornkul S, Barretto N, Peeples ME: Functional analysis of recombinant respiratory syncytial virus deletion mutants lacking the small hydrophobic and/or attachment glycoprotein gene. J Virol 200I, 75:6825-6834.

12. Teng MN, Whitehead SS, Collins PL: Contribution of the respiratory syncytial virus $G$ glycoprotein and its secreted and membrane-bound forms to virus replication in vitro and in vivo. Virology 200I, 289:283-296.

13. Whitehead SS, Bukreyev A, Teng MN, Firestone CY, St Claire M, Elkins WR, Collins PL, Murphy BR: Recombinant respiratory syncytial virus bearing a deletion of either the NS2 or SH gene is attenuated in chimpanzees. / Virol 1999, 73:3438-3442.

14. Heminway BR, Yu Y, Tanaka Y, Perrine KG, Gustafson E, Bernstein JM, Galinski MS: Analysis of respiratory syncytial virus F, G, and SH proteins in cell fusion. Virology 1994, 200:80I-805.

15. Teng MN, Collins PL: Identification of the respiratory syncytial virus proteins required for formation and passage of helperdependent infectious particles. J Virol 1998, 72:5707-5716.

16. Walsh EE, Hruska J: Monoclonal antibodies to respiratory syncytial virus proteins: identification of the fusion protein. J Virol 1983, 47:17I- 177.

17. Anderson K, Stott EJ, Wertz GW: Intracellular processing of the human respiratory syncytial virus fusion glycoprotein: amino acid substitutions affecting folding, transport and cleavage. $J$ Gen Virol 1992, 73 ( Pt 5): I |77-1 |88.

18. Bolt G, Pedersen LO, Birkeslund $\mathrm{HH}$ : Cleavage of the respiratory syncytial virus fusion protein is required for its surface expression: role of furin. Virus Res 2000, 68:25-33.

19. Collins PL, Mottet G: Post-translational processing and oligomerization of the fusion glycoprotein of human respiratory syncytial virus. J Gen Virol I991, 72 ( Pt I 2):3095-3I0I.

20. Rixon HW, Brown C, Brown G, Sugrue RJ: Multiple glycosylated forms of the respiratory syncytial virus fusion protein are expressed in virus-infected cells. J Gen Virol 2002, 83:6I-66.

21. Sugrue RJ, Brown C, Brown G, Aitken J, Mc LRHW: Furin cleavage of the respiratory syncytial virus fusion protein is not a requirement for its transport to the surface of virus-infected cells. J Gen Virol 200I, 82: I375-I 386.

22. Elango N, Satake M, Coligan JE, Norrby E, Camargo E, Venkatesan S: Respiratory syncytial virus fusion glycoprotein: nucleotide sequence of mRNA, identification of cleavage activation site and amino acid sequence of $\mathbf{N}$-terminus of FI subunit. Nucleic Acids Res 1985, 13:1559-1574.

23. Zimmer G, Trotz I, Herrler G: $\mathbf{N}$-glycans of $\mathbf{F}$ protein differentially affect fusion activity of human respiratory syncytial virus. J Virol 200I, 75:4744-475I.

24. Gonzalez-Reyes L, Ruiz-Arguello MB, Garcia-Barreno B, Calder L, Lopez JA, Albar JP, Skehel JJ, Wiley DC, Melero JA: Cleavage of the human respiratory syncytial virus fusion protein at two distinct sites is required for activation of membrane fusion. Proc Natl Acad Sci U S A 200I, 98:9859-9864.

25. Gruber C, Levine S: Respiratory syncytial virus polypeptides. III. The envelope-associated proteins. J Gen Virol 1983, 64 (Pt 4):825-832.

26. Scheid A, Choppin RW: Two disulfide-linked polypeptide chains constitute the active $\mathbf{F}$ protein of paramyxoviruses. Virology 1977, 80:54-66.

27. Ruiz-Arguello MB, Martin D, Wharton SA, Calder LJ, Martin SR, Cano O, Calero M, Garcia-Barreno B, Skehel JJ, Melero JA: Thermostability of the human respiratory syncytial virus fusion protein before and after activation: implications for the membranefusion mechanism. J Gen Virol 2004, 85:3677-3687.

28. Colman PM, Lawrence MC: The structural biology of type I viral membrane fusion. Nature Rev 2003, 4:309-319.

29. Lawless-Delmedico MK, Sista P, Sen R, Moore NC, Antczak JB, White JM, Greene RJ, Leanza KC, Matthews TJ, Lambert DM: Heptadrepeat regions of respiratory syncytial virus $\mathrm{FI}$ protein form a six-membered coiled-coil complex. Biochemistry 2000, 39: | |684-11695 
30. Matthews JM, Young TF, Tucker SP, Mackay JP: The core of the respiratory syncytial virus fusion protein is a trimeric coiled coil. jVirol 2000, 74:59। I-5920.

31. Zhao X, Singh M, Malashkevich VN, Kim PS: Structural characterization of the human respiratory syncytial virus fusion protein core. Proc Natl Acad Sci U S A 2000, 97:|4|72-14177.

32. Calder LJ, Gonzalez-Reyes L, Garcia-Barreno B, Wharton SA, Skehe J, Wiley DC, Melero JA: Electron microscopy of the human respiratory syncytial virus fusion protein and complexes that it forms with monoclonal antibodies. Virology 2000, 27 I:122-131.

33. Chen L, Colman PM, Cosgrove LJ, Lawrence MC, Lawrence LJ, Tulloch PA, Gorman J]: Cloning, expression, and crystallization of the fusion protein of Newcastle disease virus. Virology 200I, 290:290-299.

34. Chen L, Gorman J, McKimm-Breschkin J, Lawrence L, Tulloch P, Smith B, Colman P, Lawrence M: The Structure of the Fusion Glycoprotein of Newcastle Disease Virus Suggests a Novel Paradigm for the Molecular Mechanism of Membrane Fusion. Structure 200I, 9:255-266.

35. Morton CJ, Cameron R, Lawrence LJ, Lin B, Lowe M, Luttick A Mason A, McKimm-Breschkin J, Parker MW, Ryan J, Smout M, Sullivan J, Tucker SP, Young PR: Structural characterization of respiratory syncytial virus fusion inhibitor escape mutants: homology model of the $F$ protein and a syncytium formation assay. Virology 2003, 3 I I :275-288.

36. Smith BJ, Lawrence MC, Colman PM: Modelling the structure of the fusion protein from human respiratory syncytial virus. Protein Eng 2002, I 5:365-37I.

37. Yin HS, Paterson RG, Wen X, Lamb RA, Jardetzky TS: Structure of the uncleaved ectodomain of the paramyxovirus (hPIV3) fusion protein. Proc Natl Acad Sci U S A 2005, I 02:9288-9293.

38. van den Hoogen BG, Bestebroer TM, Osterhaus AD, Fouchier RA Analysis of the genomic sequence of a human metapneumovirus. Virology 2002, 295: I 19-132.

39. Iwata S, Schmidt AC, Titani K, Suzuki M, Kido H, Gotoh B, Hamaguchi $M$, Nagai $Y$ : Assignment of disulfide bridges in the fusion glycoprotein of Sendai virus. J Virol 1994, 68:3200-3206.

40. McGinnes LW, Morrison TG: Nucleotide sequence of the gene encoding the Newcastle disease virus fusion protein and comparisons of paramyxovirus fusion protein sequences. Virus Res 1986, 5:343-356.

41. Arumugham RG, Seid RC), Doyle S, Hildreth SW, Paradiso PR: Fatty acid acylation of the fusion glycoprotein of human respiratory syncytial virus. J Biol Chem I989, 264: I0339-I0342.

42. Branigan PJ, Day ND, Liu C, Gutshall LL, Melero JA, Sarisky RT, De Vecchio AM: The cytoplasmic domain of the $F$ protein of human respiratory syncytial virus is not required for cell fusion. I General Virology 2006, 87:395-398.

43. Arbiza J, Taylor G, Lopez JA, Furze J, Wyld S, Whyte P, Stott EJ, Wertz G, Sullender W. Trudel M, et al.: Characterization of two antigenic sites recognized by neutralizing monoclonal antibodies directed against the fusion glycoprotein of human respiratory syncytial virus. I Gen Virol 1992, 73 ( $\mathbf{P t}$ 9):2225-2234.

44. Branigan PJ, Liu C, Day ND, Gutshall LL, Sarisky RT, Del Vecchio AM: Use of a novel cell-based fusion reporter assay to explore the host range of human respiratory syncytial virus $F$ protein. Virol ] 2005, 2:54.

45. Toiron C, Lopez JA, Rivas G, Andreu D, Melero JA, Bruix M: Conformational studies of a short linear peptide corresponding to a major conserved neutralizing epitope of human respiratory syncytial virus fusion glycoprotein. Biopolymers 1996 39:537-548.

46. Garcia-Barreno B, Palomo C, Penas C, Delgado T, Perez-Brena P, Melero JA: Marked differences in the antigenic structure of human respiratory syncytial virus $\mathbf{F}$ and $\mathbf{G}$ glycoproteins. J Virol 1989, 63:925-932.

47. Johnson S, Oliver C, Prince GA, Hemming VG, Pfarr DS, Wang SC, Dormitzer M, O'Grady J, Koenig S, Tamura JK, Woods R, Bansal G, Couchenour D, Tsao E, Hall WC, Young JF: Development of a humanized monoclonal antibody (MEDI-493) with potent in vitro and in vivo activity against respiratory syncytial virus. J Infect Dis 1997, 176: I 215-1224.

48. Taylor G, Stott EJ, Furze J, Ford J, Sopp P: Protective epitopes on the fusion protein of respiratory syncytial virus recognized by murine and bovine monoclonal antibodies. J Gen Virol 1992, 73 ( Pt 9):2217-2223.

49. Long D, Cohen GH, Muggeridge MI, Eisenberg RJ: Cysteine mutants of herpes simplex virus type Iglycoprotein D exhibit temperature-sensitive properties in structure and function. J Virol 1990, 64:5542-5552.

50. Gharpure MA, Wright PF, Chanock RM: Temperature-sensitive mutants of respiratory syncytial virus. J Virol I969, 3:4|4-42I.

5I. Hsu KH, Crowe JEJ, Lubeck MD, Davis AR, Hung PP, Chanock RM, Murphy BR: Isolation and characterization of a highly attenuated respiratory syncytial virus (RSV) vaccine candidate by mutagenesis of the incompletely attenuated RSV A2 ts-I NG-I mutant virus. Vaccine 1995, I 3:509-5 I 5

52. Crowe JEJ, Gilmour PS, Murphy BR, Chanock RM, Duan L, Pomerantz RJ, Pilkington GR: Isolation of a second recombinant human respiratory syncytial virus monoclonal antibody fragment (Fab RSVF2-5) that exhibits therapeutic efficacy in vivo. Infect Dis 1998, I77:1073-1076.

53. Johnson S, Griego SD, Pfarr DS, Doyle ML, Woods R, Carlin D, Prince GA, Koenig S, Young JF, Dillon SB: A direct comparison of the activities of two humanized respiratory syncytial virus monoclonal antibodies: MEDI-493 and RSHZ19. J Infect Dis 1999, I 80:35-40.

54. Andries K, Moeremans M, Gevers T, Willebrords R, Sommen C, Lacrampe J, Janssens F, Wyde PR: Substituted benzimidazoles with nanomolar activity against respiratory syncytial virus. Antiviral Res 2003, 60:209-219.

55. Cianci C, Yu KL, Combrink K, Sin N, Pearce B, Wang A, Civiello R, Voss S, Luo G, Kadow K, Genovesi EV, Venables B, Gulgeze H, Trehan A, James J, Lamb L, Medina I, Roach J, Yang Z, Zadjura L, Colonno R, Clark J, Meanwell N, Krystal M: Orally active fusion inhibitor of respiratory syncytial virus. Antimicrob Agents Chemother 2004, 48:413-422.

56. Douglas JL, Panis ML, Ho E Lin KY, Krawczyk SH, Grant DM, Cai R, Swaminathan S, Cihlar T: Inhibition of respiratory syncytial virus fusion by the small molecule VP-|4637 via specific interactions with F protein. J Virol 2003, 77:5054-5064.

57. Razinkov V, Gazumyan A, Nikitenko A, Ellestad G, Krishnamurthy G: RFI-64I inhibits entry of respiratory syncytial virus via interactions with fusion protein. Chem Biol 200I, 8:645-659.

58. Sudo K, Konno K, Watanabe W, Shigeta S, Yokota T: Mechanism of selective inhibition of respiratory syncytial virus by a benzodithiin compound (RD3-0028). Microbiol Immunol 200I, 45:531-537.

59. Hogg PJ: Disulfide bonds as switches for protein function. Trends Biochem Sci 2003, 28:2 10-2 I4.

60. Barbouche R, Miquelis R, Jones IM, Fenouillet E: Protein-disulfide isomerase-mediated reduction of two disulfide bonds of HIV envelope glycoprotein 120 occurs post-CXCR4 binding and is required for fusion. J Biol Chem 2003, 278:3|3|-3|36.

61. Collins PL, Hill MG, Camargo E, Grosfeld H, Chanock RM, Murphy $B R$ : Production of infectious human respiratory syncytial virus from cloned cDNA confirms an essential role for the transcription elongation factor from the 5 ' proximal open reading frame of the M2 mRNA in gene expression and provides a capability for vaccine development. Proc Natl Acad Sci U S A 1995, 92: I|563-I|567.

Publish with Bio Med Central and every scientist can read your work free of charge

"BioMed Central will be the most significant development for disseminating the results of biomedical research in our lifetime. "

Sir Paul Nurse, Cancer Research UK

Your research papers will be:

- available free of charge to the entire biomedical community

- peer reviewed and published immediately upon acceptance

- cited in PubMed and archived on PubMed Central

- yours - you keep the copyright
BioMedcentral 